\title{
Competency Analysis of Human Resources and the Use of Information Technology on the Quality of Financial Reports in the Local Government of the City of Makassar
}

\author{
PETRUS PELENG RORENG ${ }^{1}$, MIRA BANDHASO $^{2}$, CHRISTINA JEANE TANDIRERUNG $^{3}$ \\ ${ }^{1,2,3}$ Faculty of Economics and Business, Universitas Kristen Indonesia Paulus \\ Jalan Perintis Kemerdekaan Km 13 Daya Makassar, South Sulawesi \\ INDONESIA
}

\begin{abstract}
This research is motivated because the role of human resources is very important in supporting public services. This study aims to examine the effect of human resource competence and the use of information technology on the quality of the financial reports of the Makassar City government. This research is also a quantitative approach, using primary data through interviews and questionnaires. Respondents in this study were part of the financial manager of the 26 regional work units (SKPD) of Makassar City. The variables in this study are the capacity of human resources and the use of information technology as for independent variables, and the quality of local government financial reports as the dependent variable. Data analysis used statistical methods with multiple regression analysis. The results show that the competence of human resources has a positive effect on the quality of local government financial reports. Indicates of the higher the competence of human resources in regional work unit to use of information technology has a positive effect on the quality of local government financial reports, the higher the level of use of information technology, the better it will be in producing quality local government financial reports that apply in City of Makassar. Besides of that, the leader in management should support the implementation of the local financial accounting system and internal control to order the improving of quality of local government financial report to be more optimal.
\end{abstract}

Key-words: City of Makassar, Quality of Financial, Government Financial, Human Resources.

Received: January 24, 2021. Revised: August 1, 2021. Accepted: August 12, 2021. Published: August 26, 2021.

\section{Introduction}

In the regional government, government regulations on regional financial management mandate that regional finances are managed in an orderly manner, obeying laws and regulations, effective, efficient, economical, transparent, and accountability by taking into account the principles of justice, compliance, and benefits the community. Regarding the accountability for the implementation of the Regional Revenue and Expenditure Budget (APBD), it is stated that the regional government financial reports are prepared based on the financial reports of Regional Work Units (SKPD) and submitted to the Regional Head to fulfil the accountability for implementing the APBD.

The public sector demands oblige public institutions, especially local governments, to produce quality financial reports. Transparency and accountability can realized if the Regional Government Financial Statements (LKPD) have met several qualitative characteristics as required in Government Regulation Number 71 of 2010 concerning Government Accounting Standards, namely relevant, reliable, comparable, and understandable.

Government financial reports that can meet the desired quality must have the four qualitative characteristics above as a normative prerequisite that must be manifested in accounting information to fulfil its objectives. Good quality financial reports will improve the quality of the information presented in financial reports. Financial statements are confident in making decisions because they are based on information that has been well prepared, approved, audited in a transparent, accountable, and quality manner. The quality of financial reports is the extent to which financial reports present accurate and honest information.

Adequate human resource capacity, but if it is not supported by information technology, it will not necessarily produce reliable financial reports. The Local Government Accounting System (SAPD) has a large volume of complex transactions. The use of technology will significantly assist in processing transaction data so that the resulting financial statements are free from material errors caused by human errors [1]. Success in managing regular 
arrangements for financial income and expenditure requires appropriate learning [2]

Apart from human resource competence, one thing that can affect the quality of government financial reports is the use of information technology. As we know, the total volume of the State or Regional Budget (APBN / D) from year to year shows a tremendous increase. From an accounting perspective, it shows that the volume of government financial transactions also shows a greater quantity and quality increasingly complex and complex. An increase in the volume of transactions that are getting bigger and more complex, of course, must be followed by an increase in the ability of government financial management [3].

For this reason, the Government and Regional Governments are obliged to develop and take advantage of advances in information technology to increase the capacity of public services. The mandatory use of information technology by the Government and Regional Governments is regulated in Government Regulation Number 56 of 2005 concerning Regional Financial Information Systems, a substitute for Government Regulation Number 11 of 2001 concerning Regional Financial Information. Quality financial report information will increase public confidence in local government. On the other hand, less quality information on financial reports will result in errors and fraud in the financial sector, leading to lawsuits. If irregularities occur continuously, it will cause regional financial losses. Thus, local governments should pay attention to and improve the quality of financial report information presented following regulations [4]-[17]. From that, we would like to analysis and effect of human resource competence and the use of information technology on the quality of the financial reports of the Makassar City that have not done before in City of Makassar.

\section{Problem Formulation}

The method used in this research is quantitative research methods, namely research based on the number of objects understudy that is specifically designed to determine particular objects or focus on predetermined samples. Data collection will be carried out through questionnaires that are delivered and taken by themselves. Researchers on the accounting or financial administration at SKPD will include the service, agency, office, and financial administration.

The populations in this study were all financial management staff from 54 SKPDs of Makassar City. While the sample selection using the purposive sampling method. The criteria for respondents are employees who carry out financial management consisting of Financial Administration Officers (PPK), Technical Implementation Officials (PPTK), Receiving Treasurers and Expenditure Treasurers.

The type of data used in research is primary data, namely, data obtained or collected directly by the researcher from the research object. The primary data sources will collect and study to obtain directly from employees who carry out financial management consisting of PPTK, PPK, Receiving Treasurers, and Expenditure Treasurers. They are in each SKPD in Makassar City. The data collected or obtained are then analysed using the Data Quality Test, Classical Assumption Test, and Multiple Linear Regression Test.

The analysis to test the hypothesis in this study uses multiple regression analysis. Multiple regression analysis will test the effect of two or more variables on one dependent variable [5]. Then the regression formula used is as follows:

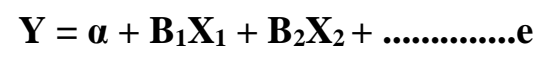

\section{Problem Solution}

\subsection{Hypothesis Test}

From the test, the effect of the independent variable on the dependent variable will test from the development of the hypothesis, namely two hypotheses. These hypotheses were analysed using multiple regression analysis. Multiple regression analysis carries out to test the effect of two or more variables on one dependent variable [5], [13]-15].

\begin{tabular}{|c|c|c|c|c|c|}
\hline \multicolumn{6}{|c|}{$\begin{array}{l}\text { Table 1. Hypothesis Test Results } \\
\text { Coefficients a }\end{array}$} \\
\hline \multirow[t]{2}{*}{ Model } & \multicolumn{2}{|c|}{$\begin{array}{c}\text { Unstandardized } \\
\text { Coefficients }\end{array}$} & \multirow{2}{*}{$\begin{array}{c}\begin{array}{c}\text { Standardized } \\
\text { Coefficients }\end{array} \\
\text { Beta }\end{array}$} & \multirow[t]{2}{*}{$t$} & \multirow[t]{2}{*}{ Sig. } \\
\hline & B & Std. Error & & & \\
\hline (Constant) & 9,509 & 4,273 & & 2,226 & 029 \\
\hline $\mathrm{X}_{1}$ &, 267 &, 128 &, 227 & 2,076 &, 041 \\
\hline $\mathrm{X}_{2}$ &, 253 &, 124 &, 229 & 2,040 &, 045 \\
\hline
\end{tabular}

Based on Table 1. above, the regression model used is as follows:

$$
Y=9.509+0.267 X_{1}+0.253 X_{2}+\ldots . . e
$$

The constant value with the regression coefficient in the above Table 1 can be explained as follows: 
1. A constant of 9.509 indicates that if the independent variables (competence of human resources and utilization of information technology) are assumed not to change (constant), then the $\mathrm{Y}$ value (quality of local government financial reports) is $9.509 \%$ units.

2. The coefficient of the human resource competency variable $\left(\mathrm{X}_{1}\right)$ of 0.267 means that with every $1 \%$ increase in the competence of human resources, and then the quality of local government financial reports will increase by $0.267 \%$.

3. The coefficient of the information technology utilization variable $\left(\mathrm{X}_{2}\right)$ is 0.253 , which means that for every $1 \%$ increase in the use of information technology, the quality of local government financial reports will increase by $0.253 \%$.

\subsection{First Hypothesis Test $\left(\mathrm{H}_{1}\right)$}

Human Resource Competence has a positive and significant effect on the quality of local government financial reports.

The first hypothesis test $\left(\mathrm{H}_{1}\right)$ results show that the human resource competency variable has a positive effect and a significance level of 0.41 and has a positive t-value of 2.076. That means accepting $\mathrm{H}_{1}$, so it said that human resource competence positively affects the quality of local government financial reports because the significance level of the human resource competency variable is less than 0,05 .

\subsection{Second Hypothesis Test $\left(\mathrm{H}_{2}\right)$}

The utilization of Information Technology has a positive and significant effect on the Quality of Regional Government Financial Reports.

The second hypothesis test (H2) also show that the variable of information technology utilization has a positive and significance level of 0.45 and has a positive t-value of 2.040. That means accepting H2, so it said that the use of information technology positively affects the quality of local government financial reports. The level of significance of the information technology utilization variable is less than 0.05 .

\section{Discussion}

a. The Influence of Human Resources
Competence on the Quality of Local
Government Financial Reports

The first hypothesis $\left(\mathrm{H}_{1}\right)$ states that human resource competence positively affects the quality of local government financial reports. The results of statistical testing following the table 1 above show, the human resource competence has a significant effect on the quality of local government financial reports. Human resource competence is the ability of a person or individual, an organization (institutional), or a system to carry out their functions or authority to achieve their goals effectively and efficiently. Competence must show the ability to achieve performance, to produce outputs and outcomes.

Based on the contingency theory in which the competence of human resources, which are the parties making financial reports, must have the appropriate competencies required in making financial reports, such as understanding roles and functions in financial management, carrying out tasks in accordance with proper accounting functions, receive training in the preparation and preparation of financial reports and if necessary have experience in the field of accounting so that they can quickly produce quality financial reports.

Local governments need professional human resources with broad insight, competence in their fields, and a competitive spirit. Professional human resources will complete their duties and jobs entirely, based on their primary tasks and functions. Qualified and competent human resources in the (financial) field are the main pillars to compile quality financial reports.

According to Tjptoherijanto (2001) in [6], assessing the capacity and quality of human resources in carrying out functions, including accounting, can be seen from the level of responsibility and competence of these human resources. Responsibility can be seen from or contained in the job description. Job descriptions are the basis for carrying out tasks properly. Without an elevating job description, these resources cannot carry out their duties properly. At the same time, competence can be seen from the educational background, the pieces of training that have been followed, and the skills expressed in implementing tasks.

Competence is a characteristic of someone who has the skills, knowledge, and ability to carry out a job [7]. According to some experts, competence is a characteristic that underlies a person to achieve high performance in his job. Employees who do not have sufficient knowledge will work intermittently and waste materials, time, and energy.

b. The Effect of Information Technology Utilization on the Quality of Local Government Financial Reports 
The second hypothesis $\left(\mathrm{H}_{2}\right)$ states that the use of information technology positively affects the quality of local government financial reports. The results of the statistical test of the table above show that the use of information technology has a significant effect on the quality of local government financial reports. According to the contingency theory, it is utilizing information technology as a financial manager. It must be able and understandable to use a computer system to make it easier for human resources to manage financial transaction data so that reports are generated and presented in a structured information system and are faster and more accurate.

The use of information technology dramatically affects the quality of local government financial reports because information technology shows as very helpful in producing quality financial reports. A local government is tools to support the implementation of activities or work such as computer hardware and software. Also, the implementation of work is more efficient and timelier in presenting local government financial reports [8]. Meanwhile, according to [9], information technology in data management has advantages in terms of speed to produce quality and timely financial reports.

A based on [10] research result, the use of information technology has a significant positive effect on the reliability of local government financial reporting. According to [11]-[12], the use of information technology has a significant positive effect on the reliability and timeliness of financial reporting. That supported by [11] and [13], research found that information technology has a significant positive effect on the quality of local government financial reports.

\section{Conclusion}

Based on the results of the discussion, it can be concluded that this study succeeded in supporting all the proposed hypotheses, the detailed explanation is as follows:

a. Competence of human resources has a positive and significant effect on the quality of local government financial reports. This shows that the higher the competence of human resources in regional work units, the better in producing the quality of local government financial reports.

b. The use of information technology has a positive and significant impact on the quality of local government financial reports. This shows that the better the application of information technology, the better the quality of local government financial reports.

\section{References:}

[1] Eldar, A. G. (2020). Problems of financial and investment support modelling of the regional social and economic development. Journal of Wseas Transactions on Business and Economics, Vol. 17, 741-752

[2] Yunus, E., Soekiman, J. F. X. S., Shichiyakh, R. A., Herningsih, \& Toding, A. (2020). Study of Shared Service Implementation to Develop a Successful Leadership Business Management System. Journal of Critical Reviews, 7(1), 267-271

[3] Li Ting, Chen Qiu Xin, Ye Qian Qian (2020). The Influence of Collaborative Innovation Among Technology, Institution and Finance on China's Economic Growth. International Journal on WSEAS Transactions on Business And Economics. Volume 17, 2020, pp. 22242899

[4] David Paul Elia Saerang, Heince R. N. Wokas, Robby J. Kumaat, and Christian Datu (2019). Effect of Understanding Financial Management, Regional Financial Accounting Systems, Effectiveness Of Internal Control, And Commitment Towards Financial Performance Of North Sulawesi Province. Accountability Journal, Volume 08, Number 01, 2019, 51-59

[5] Ghozali, Imam. (2006). Application of Multivariate Analysis with SPSS Program. Mold IV. Diponegoro University Publishing Agency, Semarang.

[6] Alimbudiono, Ria Sandra and Fidelis Arastyo Andono. (2004). Readiness of Human Resources Sub Division of Accounting of Local Government "XYZ" and its Relation to Regional Financial Accountability to the Community: Reflection for Educators' Accountants. Journal of Accounting and Public Sector Finance. Volume 5, Issue 2, 2004, pp. 18-30.

[7] Dinata, \& Anton Mulhar (2004). Review of Human Resource Readiness in Palembang City Government Institution in Local Accounting Application Towards Good Governance in the Era of Regional Autonom. Thesis. 2004. University of Sriwijaya.

[8] Erna Sari, Saiful \& Nila Aprila (2013), The Effect of Understanding Government Accounting Systems and Regional Financial 
Administration on Regional Financial Management Performance. Fairness Journal Volume 3, Number 3, 2013

[9] Donnelly, Mike, Dalrymple, J. F., \& Hollingsworth, I. P. (1994). The Use and Development of Information Systems and Technology in Scottish Local Goverment. International Journal of Public Sector Management. Volume 7, Number 3, 1994, pp. 4-15.

[10] Safrida, Nadirsyah, \& Usman. (2010). Effect of Accounting Understanding, Utilization of Regional Financial Accounting Information Systems and Internal Audit Roles on the Quality of Local Government Financial Reports. Journal of Accounting Research and Research. Volume 3, Number 2, 2010, pp. 206220.

[11] Murhaban, Iswadi, Harlinda, and Suryani (2020). The Effect of Human Resource Capacity, Information Technology Utilization, and Accounting Internal Control on the Value of Financial Statements' Information of the Lhokseumawe City Government. International Journal of Innovation, Creativity and Change, Volume 12, Number 5, 2020, pp. 609-630.

[12] Wawan Sukmana, Lia Anggarsari. 2009. Effect of Internal Supervision and Implementation of Regional Financial Accounting Systems on Local Government Performance. Accounting Journal of FE Unsil, Volume 4, Number 1, 2009

[13] Fohrurrozi, M., Purwanto, M. R., Sitaniapessy, R. H., Roreng, P. P., Toding, A. (2020). Study Of Marketing Management Using Iot. Journal of Critical Reviews, Volume 7, Number 1, 2020, pp. 294-297. doi: 10.31838/jcr.07.01.55

[14] Ferdy Van Beest, Geert Braam, and Suzanne Boelens (2009). Quality of Financial Reporting: Measuring Qualitative Characteristics. Nijmegen Center for Economics (NiCE). Working Paper 09-108 April.

[15] McDaniel. Linda, Roger D Marthin and Laureen A. Maines, (2002). Evaluating Financial Reporting Quality. Accounting Review. December 1, 2002

[16] Jensen, M. C. and W. H. Meckling. (1976). Theory of Firm: Managerial Behaviour, Agency Cost \& Ownership Structure. Journal of Financial Economics. Oktober. (Vol.3): No. 4: 305-306

[17] Wilkinson, W. Joseph, Michael J. Cerullo, Vasant Raval, and Bernard Wong-On Wing.
(2000). Accounting Information Systems: Essential Concepts and Applications. Fourth Edition. John Wiley and Sons. Inc.

Contribution of individual authors to the creation of a scientific article (ghostwriting policy)

Mira Bandhaso and Christina Jeane Tandirerung collected data and carried out the simulation and also responsible for the Statistics

Petrus Peleng Roreng has organized all the manuscripts and executed the experiments of Section 4 and also written in English

\section{Sources of funding for research presented in} a scientific article or scientific article itself

This is source of funding for research presented in a scientific article. The funding is from Universitas Kristen Indonesia Paulus Makassar, South Sulawesi Indonesia

\section{Creative Commons Attribution License 4.0}

\section{(Attribution 4.0 International, CC BY 4.0)}

This article is published under the terms of the Creative Commons Attribution License 4.0 https://creativecommons.org/licenses/by/4.0/deed.en US 